\title{
'WhiteAcre-DG', a Small-seeded, Cream-type Southernpea with an Enhanced Persistent Green Seed Phenotype
}

\author{
Richard L. Fery ${ }^{1}$ \\ U.S. Department of Agriculture, Agricultural Research Service, U.S. \\ Vegetable Laboratory, 2700 Savannah Highway, Charleston, SC 29414- \\ 5334
}

Additional index words. Vigna unguiculata, cowpea, vegetable breeding

\begin{abstract}
'WhiteAcre-DG' is a new southernpea [Vigna unguiculata (L.) Walp.] cultivar released in 2008 by the Agricultural Research Service of the U.S. Department of Agriculture. The major attribute of the new cultivar is its persistent green seed phenotype conditioned by both the green cotyledon gene $(g c)$ and the green testa (seedcoat) gene $(g t)$. 'WhiteAcre-DG' produces excellent yields of small, delicate peas that can be harvested at the dry stage of maturity without loss of the pea's fresh green color. 'WhiteAcre-DG' was developed for use by the frozen food industry as a replacement for 'White Acre'. Except for seed color, the seed characteristics of 'WhiteAcre-DG' are quite similar to those of 'White Acre'.
\end{abstract}

\section{Origin}

'WhiteAcre-DG' is the product of a pedigree-type breeding program. The parental lines are 'White Acre' (WA), 'Mississippi Silver' (MS), 'Freezegreen' (FG), and 'Bettergreen' (BG). 'White Acre', used as a parent in four of the crosses, is a late-maturity, highyielding, small-seeded, cream-type cultivar. 'Mississippi Silver' is a well-adapted, high-yielding, brown crowder-type cultivar. 'Freezegreen' and 'Bettergreen' are creamtype cultivars; 'Freezegreen' is homozygous for the green testa gene ( $g t)$ and 'Bettergreen' is homozygous for the green cotyledon gene (gc) (Chambliss, 1979; Fery and Dukes, 1994; Fery et al., 1993). The breeding scheme is relatively complex (Fig. 1). 'WhiteAcreDG' originated as a bulk of an F10 \{F5 $[((\mathrm{MS} \times \mathrm{WA}) \times \mathrm{WA}) \times \mathrm{F} 4[(\mathrm{WA} \times \mathrm{FG})] \times$ $\mathrm{F} 7[\mathrm{WA} \times \mathrm{BG}]\}$ population grown in 2001 .

\section{Description}

'WhiteAcre-DG' plants are similar in appearance to 'White Acre' plants. 'WhiteAcre-

Received for publication 14 Aug. 2008. Accepted for publication 16 Apr. 2009.

The technical assistance of Floyd P. Maguire is gratefully acknowledged.

${ }^{1}$ To whom reprint requests should be addressed; e-mail Richard.Fery@ars.usda.gov.
DG' matures to the dry-pod harvest stage at Charleston, $\mathrm{SC}$, in $\approx 62$ to $70 \mathrm{~d}$ (usually 4 to 9 d earlier than 'White Acre') (Table 1). The plant habit is high bushy. The leaf color is dark green; the leaf surface is blistered and glossy. There is no obvious purple pigmentation on the stems, branches, petioles, or peduncles. Flower color is predominantly white; the bottom of the standard (the large top petal) is yellow (the back of the standard exhibits a light yellow color; the front exhibits a tinge of yellow color on a white background).

Pod set is concentrated, and the pods are borne at the foliage level in a scattered fashion. Immature pods have a tendency to be attached to the peduncle in an erect manner; mature green pods are attached at $90^{\circ}$ from erect and dry pods are attached in a pendant manner. Each peduncle typically produces two pods. A typical dry pod is fairly straight, 13 to $14 \mathrm{~cm}$ long, and contains 15 to 16 peas. The top portion of pods ready for mature green harvest exhibits a deep purple blush color on a green background; the sutures are purple and the bottom of the pod is green. Pod color is dark green when immature and drab when dry. Fresh 'WhiteAcreDG' peas exhibit an ovate to globose shape, similar to 'White Acre' peas. The dry peas have a smooth seedcoat and are smaller than those of 'White Acre' (6.7 g versus $8.6 \mathrm{~g}$ per 100 peas, respectively).

The results of five replicated field tests conducted over a 3-year period (2005 through 2007) at Charleston, SC, indicate that 'WhiteAcre-DG' yields are comparable to other cream-type cultivars. Specifically, no yield differences could be demonstrated between the 'WhiteAcre-DG' and 'White Acre' in three of the tests, but 'WhiteAcreDG' and 'White Acre' each produced a higher yield in one of the remaining two tests. The mean dry seed yield over the five tests was not significantly different between the two cultivars ('WhiteAcre-DG', 899 $\mathrm{kg} \cdot \mathrm{ha}^{-1}$; 'White Acre', $976 \mathrm{~kg} \cdot \mathrm{ha}^{-1}$ ); however, the interaction between cultivar and trial was significant $(P \leq 0.01)$.

'WhiteAcre-DG' is homozygous for the $g c$ gene that conditions the green cotyledon trait and the $g t$ gene that conditions the green testa trait. The primary color of field-grown 'WhiteAcre-DG' peas harvested at the dry stage of maturity is a rich olive green. Dry 'WhiteAcre-DG' peas imbibed to restore fresh-harvest seed size and blanched in boiling water for $3 \mathrm{~min}$ exhibit a near-fresh green color (Fig. 2). A major attribute of the new cultivar is the persistence of the green color of the unharvested dry peas long after optimal harvest time. Unlike the green cotyledon phenotype parent, 'Bettergreen', in which growers must harvest the crop immediately after pod drying to ensure a high-color product, growers of 'WhiteAcre-DG' have a considerably greater harvest window.

'WhiteAcre-DG' is recommended for use by the frozen food industry. The frozen food industry can imbibe the dry peas in water and use the resulting raw product to produce a pack that closely approximates the color and appearance of a pack prepared using fresh 'White Acre' peas. Imbibed and blanched 'WhiteAcre-DG' and 'White Acre' seeds can be readily blended (packed together) to produce a retail product with the desired intensity of green color.

\section{Availability}

Breeder's seed of 'WhiteAcre-DG' has been released to seed producers. Small samples of 'WhiteAcre-DG' breeder's seed are available from the author for distribution to interested research personnel. Genetic material of this release will be deposited in the National Plant Germplasm System where it will be available for research purposes, including development and commercialization of new cultivars. It is requested that appropriate recognition of the source be given when this germplasm contributes to 
Table 1. Number of days to harvest, weight per 100 dry peas, and dry pea yield for 'White Acre', 'Green Pixie', 'Double Green Delight', and 'WhiteAcre-DG' cream-type southernpeas grown in five separate trials at Charleston, SC, 2005-2007.

\begin{tabular}{|c|c|c|c|}
\hline Trial/cultivar & $\begin{array}{l}\text { Days to harvest } \\
\text { (no.) }\end{array}$ & $\begin{array}{c}\text { Wt./100 dry peas } \\
(\mathrm{g})\end{array}$ & $\begin{array}{l}\text { Dry pea yield } \\
\left(\mathrm{kg} \cdot \mathrm{ha}^{-1}\right)\end{array}$ \\
\hline \multicolumn{4}{|l|}{ Trial I } \\
\hline White Acre & $74.6 \mathrm{a}^{\mathrm{y}}$ & $11.1 \mathrm{~b}$ & $591 \mathrm{~b}$ \\
\hline Green Pixie & $68.2 \mathrm{c}$ & $9.2 \mathrm{c}$ & $854 \mathrm{a}$ \\
\hline DoubleGreen Delight & $68.8 \mathrm{bc}$ & $11.6 \mathrm{a}$ & $792 \mathrm{a}$ \\
\hline WhiteAcre-DG & $70.2 \mathrm{~b}$ & $8.0 \mathrm{~d}$ & $726 \mathrm{a}$ \\
\hline \multicolumn{4}{|l|}{ Trial II } \\
\hline White Acre & $74.1 \mathrm{a}$ & $7.2 \mathrm{~b}$ & $1,406 \mathrm{a}$ \\
\hline Green Pixie & $70.8 \mathrm{~b}$ & $6.9 \mathrm{~b}$ & $1,132 \mathrm{~b}$ \\
\hline DoubleGreen Delight & $69.0 \mathrm{c}$ & $9.5 \mathrm{a}$ & $1,335 \mathrm{a}$ \\
\hline WhiteAcre-DG & $69.3 \mathrm{c}$ & $6.3 \mathrm{c}$ & $1,135 \mathrm{~b}$ \\
\hline \multicolumn{4}{|l|}{ Trial III } \\
\hline White Acre & $71.3 \mathrm{a}$ & $9.0 \mathrm{a}$ & $851 \mathrm{a}$ \\
\hline Green Pixie & $65.5 \mathrm{~b}$ & $8.0 \mathrm{~b}$ & $645 \mathrm{a}$ \\
\hline DoubleGreen Delight & $64.2 \mathrm{bc}$ & $9.2 \mathrm{a}$ & $873 \mathrm{a}$ \\
\hline WhiteAcre-DG & $62.0 \mathrm{c}$ & $5.7 \mathrm{c}$ & $695 \mathrm{a}$ \\
\hline \multicolumn{4}{|l|}{ Trial IV } \\
\hline White Acre & - & $6.8 \mathrm{c}$ & $1,130 \mathrm{a}$ \\
\hline Green Pixie & - & $7.2 \mathrm{~b}$ & $1,140 \mathrm{a}$ \\
\hline DoubleGreen Delight & - & $9.1 \mathrm{a}$ & $1,192 \mathrm{a}$ \\
\hline WhiteAcre-DG & - & $6.3 \mathrm{~d}$ & $1,081 \mathrm{a}$ \\
\hline \multicolumn{4}{|l|}{ Trial V } \\
\hline White Acre & $68.0 \mathrm{a}$ & $8.8 \mathrm{~b}$ & $852 \mathrm{~b}$ \\
\hline Green Pixie & $63.2 \mathrm{c}$ & $8.1 \mathrm{c}$ & $788 \mathrm{~b}$ \\
\hline DoubleGreen Delight & $65.4 \mathrm{~b}$ & $10.8 \mathrm{a}$ & $1,018 \mathrm{a}$ \\
\hline WhiteAcre-DG & $63.6 \mathrm{c}$ & $6.6 \mathrm{~d}$ & $776 \mathrm{~b}$ \\
\hline \multicolumn{4}{|c|}{ Combined analysis of all trials } \\
\hline White Acre & $72.1 \mathrm{a}^{* * *}$ & $8.6 b^{* * *}$ & $976 b^{* *}$ \\
\hline Green Pixie & $67.1 \mathrm{~b}$ & $7.9 \mathrm{c}$ & $935 \mathrm{~b}$ \\
\hline DoubleGreen Delight & $67.1 \mathrm{~b}$ & $10.1 \mathrm{a}$ & $1,057 \mathrm{a}$ \\
\hline WhiteAcre-DG & $66.8 \mathrm{~b}$ & $6.7 \mathrm{~d}$ & $899 \mathrm{~b}$ \\
\hline
\end{tabular}

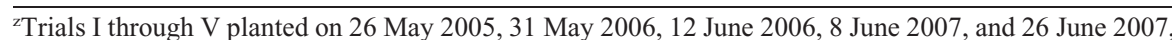
respectively. Experimental design of each trial was a randomized complete block with six replications (Trial III) or 10 replications (Trials I, II, IV, and V). Each plot was space-planted, 18 hills per plot, three seeds per hill, $30 \mathrm{~cm}$ between hills, and $102 \mathrm{~cm}$ between rows; the center 16 hills of each plot were handharvested to simulate a single, once-over, mechanical harvest.

${ }^{\mathrm{y}}$ Mean separation within columns and trials by the Student-Newman-Keuls multiple range test $(P \leq 0.05)$. **, ***Significant interaction between cultivar and trial at $P \leq 0.01$ or $P \leq 0.001$, respectively.

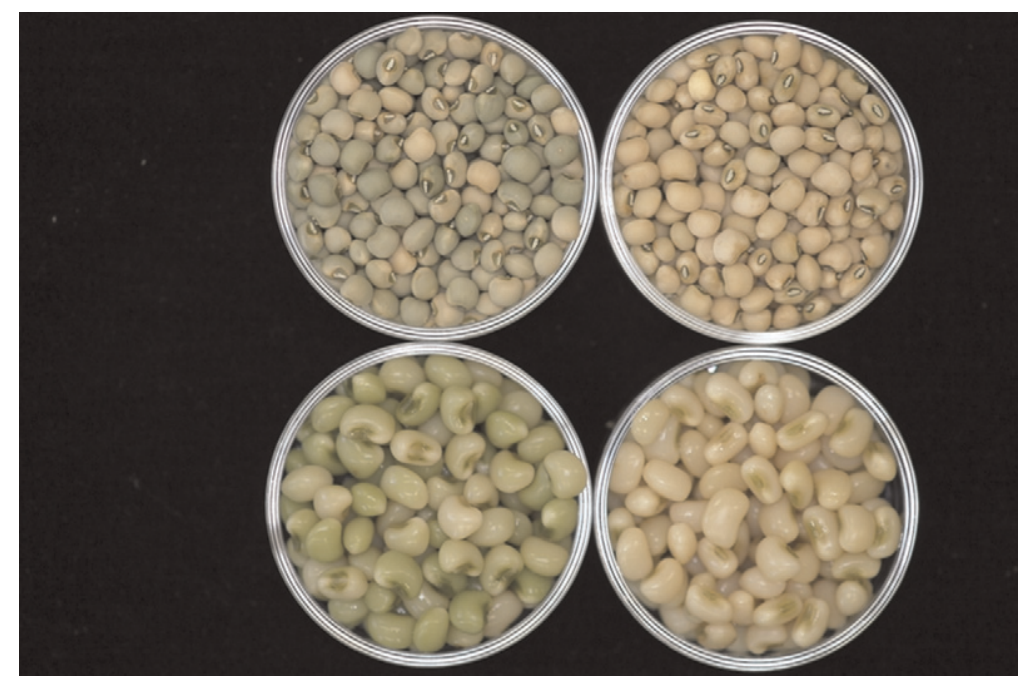

Fig. 2. Dried seeds (top) and dried seeds imbibed to restore fresh-harvest seed size and blanched in boiling water for $3 \mathrm{~min}$ (bottom) of 'WhiteAcre-DG' (left) and 'White Acre' (right). Note the green color of both the dried and imbibed seeds of 'WhiteAcre-DG' $(g c / g c g t / g t)$ and the cream color of both the dried and imbibed seeds of 'WhiteAcre' $(G c / G c G t / G t)$. research or development of a new breeding line or cultivar.

\section{Literature Cited}

Chambliss, O.L. 1979. 'Freezegreen' southernpea. HortScience 14:193.

Fery, R.L. and P.D. Dukes. 1994. Genetic analysis of the green cotyledon trait in southernpea [Vigna unguiculata (L.) Walp.]. J. Amer. Soc. Hort. Sci. 119:1054-1056.

Fery, R.L., P.D. Dukes, and F.P. Maguire. 1993. 'Bettergreen' southernpea. HortScience 28:856. 